\title{
THE DEVELOPMENT OF STUDENTS APPLIED MATHEMATICAL THINKING IN TEACHING INVERSE AND ILL-POSED PROBLEMS
}

\author{
V.S. Kornilov \\ Moscow city pedagogical university \\ Sheremetyevskaya str., 29, Moscow, Russia, 127521
}

In the article the author draws the reader's attention to the fact that, while mastering the process of learning the theory and methodology of inverse and ill-posed problems, students not only form the fundamental knowledge in the field of inverse and ill-posed problems, applied and computational mathematics, mathematical modeling of processes and phenomena, but also develop one of the most important component of mathematical ability creative and applied mathematical thinking.

It is emphasized that the search for solutions to inverse and ill-posed problems, students acquire profound knowledge in such scientific fields as seismology, gravimetry, magnetometry, Geophysics, astrophysics, imaging, electrodynamics, atmospheric optics, quantum scattering theory and other scientific fields. When teaching inverse and ill-posed problems, students also learn the mathematical methods, which are not included in the content of traditional mathematics applied and computational mathematics, and can only be purchased in the teaching of special courses. Among them, spectral analysis, the method of Volterra operator equations, Sobolev method, method of scales of Banach spaces of analytic functions, the method of integral geometry, the method of tensor analysis, methods of computational mathematics and other mathematical methods.

Key words: training the inverse and ill-posed problems, applied mathematical thinking, applied mathematics, computational mathematics, student

Currently, in many Russian universities prepare highly qualified specialists in the field of applied mathematics. In the process of teaching applied mathematics, students acquire fundamental knowledge of mathematical and functional analysis, algebra and geometry, ordinary differential equations and equations of mathematical physics, numerical methods, computer technology and other subject areas, acquire skills of research of applied problems using mathematical modeling and computing experiment. As a result, these graduates in their professional activities to acquire new knowledge about the world is able to build correct mathematical models of the studied processes and applied to explore effective methods of modern world science. The presence of such graduates noted the professional qualities demonstrates their competence in the field of applied mathematics and the existence of mathematical thinking.

The study of psychological and pedagogical aspects of students' mathematical thinking devoted to the work Z.S. Akhmanova, O.Z. Artebaleno, G.I. Bavrina, T.G. Zakharova, I.I. Kuleshova, G.L. Lukankin, T.V. Myasnikova, E.J. Pantziou, E.I. Smirnov, V.N. Khudyakov and other authors (see for example, $[1 ; 2 ; 6 ; 9 ; 18 ; 20 ; 21 ; 23 ; 26 ; 28$; 29]). A certain contribution to the formation of students ' physical and mathematical 
specialties of higher educational institutions applied mathematical thinking makes training inverse and ill-posed problems (see for example, $[3 ; 7-19 ; 24 ; 27])$. The content of this training is based on the theory of inverse and ill-posed - one of the areas of modern applied mathematics.

Broad interest in inverse and ill-posed problems due to their great practical importance. This research area is applied mathematics develops in the research of Y.E. Anikonov, A.V. Baev, M.I. Belishev, P.N. Vabishevich, V.V. Vasin, A.O. Vatulyan, A.V. Goncharskii, A.M. Denisov, V.K. Ivanov, S.I. Kabanikhin, M.M. Lavrent'ev, V.V. Pikalov, V.G. Romanov, V.P. Tanana, A.N. Tikhonov, A.M. Fedotov, V.A. Cheverda, V.G. Cherednichenko, V.A. Yurko and other scholars (see for example, $[4 ; 5 ; 22 ; 24 ; 25 ; 27 ; 30]$ ).

Inverse and ill-posed problems taught to students of senior courses of physicalmathematical specialties, and it is assumed that they have fundamental knowledge in many disciplines of applied and computational mathematics, as mathematical models of inverse and ill-posed problems are atypical mathematical problems, search not template solutions which involves conducting in-depth analysis of the studied physical process and its cause-and-effect relationships. In the study of mathematical models of inverse and ill-posed problems, depending on their types, types and performances, students will acquire the skills to generate new scientific knowledge about the world, about what is happening in it of physical processes and phenomena and their causal relations.

We give some examples.

1. In the study of mathematical models of inverse problems of seismology, students acquire scientific knowledge about seismology, the study of the nature of elastic vibrations of the Earth. Depending on the performances of these inverse problems, students have to analyze and use information about the properties of the sources of the elastic fields, the structure of the earth through which seismic waves propagate.

2 . In the study of mathematical models of inverse problems of gravimetry and magnetometry, the students form new scientific knowledge, for example, on the characteristics of the sources observed on the Earth's surface the gravitational field on the continuation of potential fields in the direction of the sources.

3. In the study of mathematical models of inverse problems of astrophysics, students acquire scientific knowledge, for example, about the interpretation of observations of close binary systems, the motion of a pair of stars under the influence of mutual attraction, about the important characteristics of stars.

4. In the study of mathematical models of inverse problems of processing of images, students form scientific knowledge in the field of pattern recognition, reconstruction of blurred and defocused images, imaging.

5. In the study of mathematical models of inverse problems of electrodynamics, the students form scientific knowledge, for example, on the processing and interpretation of the results of measuring electromagnetic radiation produced by various objects, sources of electromagnetic fields, the forms of bodies, in which the scattering of the field inhomogeneities on the earth's environment, the synthesis of the electromagnetic field.

6. In the study of mathematical models of inverse problems of atmospheric optics, students form scientific knowledge, for example, on the physical state of the atmosphere, concentration of absorbing and scattering substances, sizes and shapes of aerosol particles, 
their composition and structure, about the parameters of the fine structure of the spectrum, the intensity of the radiation.

7. In the study of mathematical models of inverse problems of determining the density of heat sources, students acquire scientific knowledge, for example, on the density of radioactive heat sources on the thermal radiation on the Earth's surface, the half-life of radioactive elements.

8. In the study of mathematical models of inverse problems for differential equations of elasticity students master scientific knowledge, for example, in the linear theory of elasticity, in particular, about the ball isotropy of perfect elasticity, of the linear dependence between stress and strain, small deformation, on the external surface and volume forces, about the natural state of the body.

When finding solutions to mathematical models of inverse and ill-posed, the students also acquire new scientific knowledge in subject areas that are not included in the content of traditional mathematics applied and computational mathematics, and can only be purchased in the teaching of special courses. For clarity, we give examples.

1. In the study of mathematical models of inverse spectral problems, students acquire scientific knowledge in the field of spectral analysis is to define operators on some of their spectral characteristics. Students were aware that such a mathematical model of the inverse problems play an important role in applications of physics, quantum mechanics, Geophysics, meteorology, electronics, elasticity theory, and other applications. In the process of solving such inverse problems, students master the method of spectral mappings the method of standard models, the method of operator transformations, and other mathematical methods.

2. In the study of mathematical models of dynamic inverse problems for hyperbolic equations, students master the idea of the method of Volterra operator equations, optimization method of linearization, a method for the treatment difference schemes and other methods. Gaining skills to operate the functional spaces to perform mathematical operations on generalized functions, linear operators. Gain experience of applying the method of Sobolev, method, scales of Banach spaces of analytic functions, methods of integral geometry methods of tensor analysis theorem C.V. Kovalevskaya theorem S. Banach and other methods and theorems in seeking solutions to such inverse problems.

3 . In the study of mathematical models of inverse boundary problems of Aero-and hydrodynamics students acquire substantive scientific knowledge, for example, in the design of airfoils, which have the desired characteristics, mastering such fundamental concepts as source, vortex, flow, geometry of the profile around the profile, the flow is inhibited layers, master the methods of aerodynamic design and other methods. The students in the solution of such inverse problems master the mathematical methods of determining the shape of the profile when there is known on his circuit of the velocity distribution, methods of flow ideal fluid, methods of the theory of analytical functions and other methods.

4. In the study of mathematical models of inverse and ill-posed problems with approximate methods, students acquire in-depth scientific knowledge in the field of computational mathematics. Among such scientific knowledge - the theory of difference schemes, finite-difference methods sweep method, iterative methods, regularization 
method A.N. Tikhonov, the method of the Newton-Kontorovich, gradient methods, the discrete analogue of the Volterra operator equations with partially Lipschitz-continuous kernel. Develop methods of error estimates for approximate solutions of inverse and illposed problems to the exact solutions and other methods. The students extensively use computer technology for implementing computational algorithms for searching approximate solutions of the inverse and ill-posed problems that demonstrate to students their efficiency and mobility in the study applied.

In the process of solutions to inverse and ill-posed problems, students gain skills to independently formulate logical conclusions of applied and humanitarian nature. It is obvious that such students are formed as fundamental scientific knowledge in inverse and ill-posed tasks, applied mathematics, computational mathematics, and developing mathematical thinking.

\section{LITERATURE}

[1] Акманова 3.С. Развитие математической культуры студентов университета в процессе профессиональной подготовки: дисс. ... канд. пед. наук. Магнитогорск, 2005. $171 \mathrm{c.}$

[2] Артебякина О.В. Формирование математической культуры у студентов педагогических вузов: дисс. ... канд. пед. наук. Челябинск, 1999. 162 с.

[3] Бидайбеков Е.Ы., Корнилов В.С., Камалова Г.Б. Обучение будущих учителей математики и информатики обратным задачам для дифференциальных уравнений // Вестник Московского городского педагогического университета. Серия «Информатика и информатизация образования». 2014. № 3 (29). С. 57-69.

[4] Гончарский А.В., Черепащук А.М., Ягода А.Г. Численные методы решения обратных задач астрофизики: монография. М.: Наука, 1978. 335 с.

[5] Елизаров А.М., Ильинский Н.Б., Поташев А.В. Обратные краевые задачи аэрогидродинамики: монография. М.: Наука, 1994. 440 с.

[6] Захарова T.Г. Формирование математической культуры в условиях профессиональной подготовки студентов вуза: дисс. ... канд. пед. наук. Саратов, 2005. 173 с.

[7] Корнилов В.С. О междисциплинарном характере исследований причинно-следственных обратных задач // Вестник Московского городского педагогического университета. Серия «Информатика и информатизация образования». 2004. № 1 (2). С. 80-83.

[8] Корнилов B.C. Основы методической системы обучения дисциплине «Обратные задачи для дифференциальных уравнений» // Вестник Самарского государственного экономического университета. Самара: СГЭУ, 2005. № 3 (18). С. 190-196.

[9] Корнилов B.C. Обучение обратным задачам для дифференциальных уравнений как фактор гуманитаризации математического образования: монография. М.: МГПУ, 2006. 320 с.

[10] Корнилов B.C. Гуманитарные аспекты вузовской системы прикладной математической подготовки // Наука и школа. 2007. № 5. С. 23-28.

[11] Корнилов В.С. Психологические аспекты обучения студентов вузов фрактальным множествам // Вестник Российского университета дружбы народов. Серия: «Информатизация образования». 2011. № 4. С. 79-82.

[12] Корнилов B.C. Обратные задачи в учебных дисциплинах прикладной математики // Вестник Московского городского педагогического университета. Серия «Информатика и информатизация образования». 2014. № 1 (27). С. 60-68.

[13] Корнилов B.C. Экологическая составляющая гуманитарного потенциала обучения обратным задачам для дифференциальных уравнений // Традиции гуманизации в образовании: Сборник материалов III Межд. конф. памяти Г.В. Дорофеева (г. Москва 23 июня 2014 г.). М.: ИСМО РАО, 2014. С. 63-65. 
[14] Корнилов В.С. Обучение студентов обратным задачам математической физики как фактор формирования фундаментальных знаний по интегральным уравнениям // Бюллетень лаборатории математического, естественнонаучного образования и информатизации. Рецензируемый сборник научных трудов. Самара: Самарский филиал МГПУ, 2015. Том VI. C. 251-257.

[15] Корнилов B.C. Формирование фундаментальных знаний будущих учителей информатики и математики по функциональному анализу при обучении обратным задачам математической физики // Вестник Московского городского педагогического университета. Серия «Информатика и информатизация образования». 2015. № 3 (33). С. 72-82.

[16] Корнилов B.C. Реализация научно-образовательного потенциала обучения студентов вузов обратным задачам для дифференциальных уравнений // Казанский педагогический журнал. 2016. № 6. С. 55-59.

[17] Корнилов B.C. Реализация методов вычислительной математики при обучении студентов обратным задачам для дифференциальных уравнений // Вестник Московского городского педагогического университета. Серия «Информатика и информатизация образования». 2016. № 2 (36). С. 91-100.

[18] Корнилов В.C. Теория и методика обучения обратным задачам для дифференциальных уравнений: монография. М.: Изд-во «ОнтоПринт», 2017. 500 с.

[19] Корнилов В.С. Формирование фундаментальных знаний по математическому моделированию при обучении обратным задачам для дифференциальных уравнений // Вестник Московского городского педагогического университета. Серия «Информатика и информатизация образования». 2017. № 1 (39). С. 92-99.

[20] Кулешова И.И. Формирование математической культуры студентов технических вузов на основе технологии модульного обучения: дисс. ... канд. пед. наук. Барнаул, 2003. 160 с.

[21] Мясникова T.B. Творческий потенциал студента и его развитие в условиях студенческого научного общества // Молодой ученый. 2014. № 18. С. 614-616.

[22] Некорректные задачи естествознания: сб. научн. тр. / под ред. А.Н. Тихонова, А.В. Гончарского. М.: Изд-во Московского университета, 1987. 299 с.

[23] Панцева Е.Ю. Математическая культура - аспект профессиональной культуры // Научно-методический электронный журнал «Концепт». 2014. T. 20. C. 1496-1500. URL: http://e-koncept.ru/2014/54563.htm (дата обращения: ).

[24] Романов В.Г. Обратные задачи математической физики: монография. М.: Наука, 1984. $264 \mathrm{c}$.

[25] Самарский А.А., Вабишевич П.Н. Численные методы решения обратных задач математической физики: монография. М.: УРСС, 2004. 478 с.

[26] Смирнов Е.И. Дидактическая система математического образования студентов педагогических вузов: дисс. ... д-ра пед. наук. Ярославль, 1998. 358 с.

[27] Трофимов Ю.М., Поляков А.В. Математические аспекты решения обратных задач атмосферной оптики: учеб. пособие. СПб.: Изд-во Санкт-Петербургского университета, 2001. $188 \mathrm{c}$.

[28] Худяков B.Н. Формирование математической культуры учащихся начального профессионального образования: дисс. ... Д-ра пед. наук. Магнитогорск, 2001. 349 с.

[29] Хуторской А.В. Современная дидактика: учеб. пособие. М.: Высшая школа, 2007. 639 с.

[30] Юрко B.A. Введение в теорию обратных спектральных задач: монография. М.: Физматлит, 2007. $384 \mathrm{c}$.

Cornilov V.S., 2017

\section{Article history:}

Received: 20 June, 2017

Accepted: 25 Jule, 2017 
For citation:

Kornilov V.S. (2017). The development of students applied mathematical thinking in teaching inverse and Ill-Posed problems. RUDN Journal of Informatization Education, 14 (4), 493-501. DOI 10.22363/2312-8631-2017-14-4-493-501

\title{
Bio Note:
}

Kornilov Viktor Semenovich, doctor of pedagogical sciences, candidate of physical and mathematical sciences, full professor, deputy head of the department of informatization of education of the Moscow city pedagogical university. Contact information: e-mail: vs_kornilov@mail.ru

\section{РАЗВИТИЕ У СТУДЕНТОВ ПРИКЛАДНОГО МАТЕМАТИЧЕСКОГО МЫШЛЕНИЯ ПРИ ОБУЧЕНИИ ОБРАТНЫМ И НЕКОРРЕКТНЫМ ЗАДАЧАМ}

\author{
В.С. Корнилов \\ Московский городской педагогический университет \\ Шереметьевская ул., 29, Москва, Россия, 127521
}

\begin{abstract}
В статье автор обращает внимание читателя на то, что, осваивая в процессе обучения теорию и методологию исследования обратных и некорректных задач, студенты не только формируют фундаментальные знания в области обратных и некорректных задач, прикладной и вычислительной математики, математического моделирования процессов и явлений, но и развивают одну из важных компонент творческих математических способностей - прикладное математическое мышление.

Подчеркивается, что при поиске решений обратных и некорректных задач студенты приобретают глубокие знания в таких научных областях, как сейсмология, гравиметрия, магнитометрия, геофизика, астрофизика, томография, электродинамика, атмосферная оптика, квантовая теория рассеяния и другие научные области. При обучении обратным и некорректным задачам студенты также осваивают математические методы, которые не входят в содержание традиционных математических дисциплин прикладной и вычислительной математики, а могут быть приобретены только в процессе преподавания специальных курсов. Среди них спектральный анализ, метод операторных уравнений Вольтерра, метод С.Л. Соболева, метод шкал банаховых пространств аналитических функций, метод интегральной геометрии, метод тензорного анализа, методы вычислительной математики и другие математические методы.
\end{abstract}

Ключевые слова: обучение обратным и некорректным задачам, прикладное математическое мышление, прикладная математика, вычислительная математика, студент

\section{REFERENCES}

[1] Akmanova Z.S. Razvitie matematicheskoj kul'tury studentov universiteta v processe professional'noj podgotovki [The development of mathematical culture of students of the university in the process of vocational training]: diss. ... kand. ped. nauk. Magnitogorsk, 2005. $171 \mathrm{p}$.

[2] Artebjakina O.V. Formirovanie matematicheskoj kul'tury u studentov pedagogicheskih vuzov [Formation of mathematical culture of students of pedagogical universities]: diss. ... kand. ped. nauk. Chelyabinsk, 1999. 162 p.

[3] Bidaibekov E.S., Kornilov V.S., Kamalova G.B. Obuchenie budushhih uchitelej matematiki $i$ informatiki obratnym zadacham dlja differencial'nyh uravnenij [The training of future teachers of 
mathematics and Informatics inverse problems for differential equations]. Vestnik Moskovskogo gorodskogo pedagogicheskogo universiteta. Serija «Informatika i informatizacija obrazovanija» [Bulletin of the Moscow city pedagogical university. "Informatics and Informatization of Education" series]. 2014. No. 3 (29). Pp. 57-69.

[4] Goncharskii A.V., Cherepashchuk A.M., Yagoda A.G. Chislennye metody reshenija obratnyh zadach astrofiziki [Numerical methods for solving inverse problems of astrophysics]: monografija. M.: Nauka, 1978. 335 p.

[5] Elizarov A.M., Ilyinsky N.B., Potashev A.V. Obratnye kraevye zadachi ajerogidrodinamiki [Inverse boundary value problem of aerohydrodynamics]: monografija. Moscow: Nauka, 1994. 440 p.

[6] Zaharova T.G. Formirovanie matematicheskoj kul'tury v uslovijah professional'noj podgotovki studentov vuza [Formation of mathematical culture in the conditions of professional training of students of the University]: diss. ... kand. ped. nauk. Saratov, 2005. 173 p.

[7] Kornilov V.S. O mezhdisciplinarnom haraktere issledovanij prichinno-sledstvennyh obratnyh zadach [About cross-disciplinary character of researches of cause and effect inverse problems]. Vestnik Moskovskogo gorodskogo pedagogicheskogo universiteta. Serija «Informatika i informatizacija obrazovanija» [Bulletin of the Moscow city pedagogical university. "Informatics and Informatization of Education" series]. 2004. No. 1 (2). Pp. 80-83.

[8] Kornilov V.S. Osnovy metodicheskoj sistemy obuchenija discipline «Obratnye zadachi dlja differencial'nyh uravnenij» [Bases of methodical system of training in discipline "The inverse problems for the differential equations"]. Vestnik Samarskogo gosudarstvennogo jekonomicheskogo universiteta [Bulletin of the Samara state economic university]. 2005. No. 3 (18). Pp. 190-196.

[9] Kornilov V.S. Obuchenie obratnym zadacham dlja differencial'nyh uravnenij kak faktorgumanitarizacii matematicheskogo obrazovanija [Training in the inverse problems for the differential equations as a factor of humanitarization of mathematical education]: monografija. M.: MGPU, 2006. $320 \mathrm{p}$.

[10] Kornilov V.S. Gumanitarnye aspekty vuzovskoj sistemy prikladnoj matematicheskoj podgotovki [Humanitarian aspects of high school system of applied mathematical preparation]. Nauka $i$ shkola [Science and school]. 2007. No. 5. Pp. 23-28.

[11] Kornilov V.S. Psihologicheskie aspekty obuchenija studentov vuzov fraktal'nym mnozhestvam [Psychological aspects of training of students of higher education institutions in fractal sets]. Vestnik Rossijskogo universiteta druzhby narodov. Serija «Informatizacija obrazovanija» [Bulletin of the Russian university of friendship of the people. "Education Informatization" series]. 2011. No. 4. Pp. $79-82$.

[12] Kornilov V.S. Obratnye zadachi v uchebnyh disciplinah prikladnoj matematiki [Inverse problems in the educational disciplines of applied mathematics]. Vestnik Moskovskogo gorodskogo pedagogicheskogo universiteta. Serija «Informatika i informatizacija obrazovanija» [Bulletin of the Moscow city pedagogical university. "Informatics and Informatization of Education" series]. 2014. No. 1 (27). Pp. 60-68.

[13] Kornilov V.S. Jekologicheskaja sostavljajushhaja gumanitarnogo potenciala obuchenija obratnym zadacham dlja differencial'ny h uravnenij [The ecological component of the humanitarian potential of learning inverse problems for differential equations]. Tradicii gumanizacii vobrazovanii: Sbornik materialov III Mezhdunarodnoj konferencii pamjati G.V. Dorofeeva (Moskva 23 ijunja 2014 g.) [Traditions of humanization in education: proceedings of the III International conference in memory of G. V. Dorofeeva (Moscow 23 June 2014)]. M.: ISMO RAO, 2014. Pp. 63-65.

[14] Kornilov V.S. Obuchenie studentovobratnym zadacham matematicheskojfiziki kak factorformirovanija fundamental'nyh znanij po integral'nym uravnenijam [Training of students in the inverse problems of mathematical physics as factor of formation of fundamental knowledge of the integrated equations]. Bjulleten' laboratorii matematicheskogo, estestvennonauchnogo obrazovanija $i$ informatizacii. Recenziruemyj sbornik nauchnyh trudov [Bulletin of laboratory of mathematical, natural-science education and informatization. The reviewed collection of scientific work]. Samara: Samarskij filial MGPU, 2015. T. VI. Pp. 251-257.

[15] Kornilov V.S. Formirovanie fundamental'nyh znanij budushhih uchitelej informatiki i matematiki po funkcional'nomu analizu pri obuchenii obratnym zadacham matematicheskoj fiziki [Formation of fundamental knowledge of future teachers of informatics and mathematics of the functional 
analysis when training in the inverse problems of mathematical physics]. Vestnik Moskovskogo gorodskogo pedagogicheskogo universiteta. Serija «Informatika i informatizacija obrazovanija» [Bulletin of the Moscow city pedagogical university. "Informatics and Informatization of Education" series]. 2015. No. 3 (33). Pp. 72-82.

[16] Kornilov V.S. Realizacija nauchno-obrazovatel'nogo potenciala obuchenija studentov vuzovobratnym zadacham dlja differencial'nyh uravnenij [Realization of scientific and educational potential of training of students of higher education institutions in the inverse problems for the differential equations]. Kazanskij pedagogicheskij zhurnal [Kazan pedagogical journal]. 2016. No. 6. Pp. 5559.

[17] Kornilov V.S. Realizacija metodov vychislitel'noj matematiki pri obuchenii studentov obratnym zadacham dlja differencial'nyh uravnenij [Implementation of methods of computational mathematics in teaching of inverse problems for differential equations]. Vestnik Moskovskogo gorodskogo pedagogicheskogo universiteta. Serija «Informatika i informatizacija obrazovanija» [Bulletin of the Moscow city pedagogical university. "Informatics and Informatization of Education" series]. 2016. No. 2 (36). Pp. 91-100.

[18] Kornilov V.S. Teorija i metodika obuchenija obratnym zadacham dlja differencial'nyh uravnenij [Theory and technique of training to the inverse problems for differential equations]: monografija. M.: Izd-vo «OntoPrint», 2017. 500 p.

[19] Kornilov V.S. Formirovanie fundamental'nyh znanij po matematicheskomu modelirovaniju pri obuchenii obratnym zadacham dlja differencial'nyh uravnenij [Formation of fundamental knowledge of mathematical modeling when training in the return tasks for the differential equations]. Vestnik Moskovskogo gorodskogo pedagogicheskogo universiteta. Serija "Informatika i informatizacija obrazovanija» [Bulletin of the Moscow city pedagogical university. "Informatics and Informatization of Education" series]. 2017. No. 1 (39). Pp. 92-99.

[20] Kuleshova I.I. Formirovanie matematicheskoj kul'tury studentov tehnicheskih vuzov na osnove tehnologii modul'nogo obuchenija [Formation of mathematical culture of students of technical universities on the basis of the technology of modular training]: diss. ... kand. ped. nauk. Barnaul, 2003. $160 \mathrm{p}$.

[21] Mjasnikova T.V. Tvorcheskij potencial studenta i ego razvitie v uslovijah studencheskogo nauchnogo obshhestva [The creative potential of the student and his development in terms of the student scientific society]. Molodoj uchenyj [Young scientist]. 2014. No. 18. Pp. 614-616.

[22] Nekorrektnye zadachi estestvoznanija [Ill-posed problems of natural science]: Sb. nauchn. tr. / Pod redakciej A.N. Tihonova, A.V. Goncharskogo. M.: Izd-vo Moskovskogo universiteta, 1987. $299 \mathrm{p}$.

[23] Panceva E.Ju. Matematicheskaja kul'tura - aspekt professional'noj kul'tury [Mathematical culture is the aspect of professional culture]. Nauchno-metodicheskij jelektronnyj zhurnal «Koncept» [Scientific-methodical electronic journal "Concept"]. 2014. No. 20. Pp. 1496-1500. URL: http://e-koncept.ru/2014/54563.htm

[24] Romanov V.G. Obratnye zadachi matematicheskojfiziki [Inverse problems of mathematical physics]: monografija. M.: Nauka, 1984. 264 p.

[25] Samarskij A.A., Vabishevich P.N. Chislennye metody reshenija obratnyh zadach matematicheskoj fiziki [Numerical methods of the solution of the inverse problems of mathematical physics]: monografija. M.: Editorial URSS, 2004. 480 p.

[26] Smirnov E.I. Didakticheskaja sistema matematicheskogo obrazovanija studentov pedagogicheskih vuzov [The didactical system of mathematical education of students of pedagogical universities]: diss. ... d-ra ped. nauk. Jaroslavl', 1998. 358 p.

[27] Trofimov Ju.M., Poljakov A.V. Matematicheskie aspekty reshenija obratnyh zadach atmosfernoj optiki: uchebnoe posobie. SPb.: Izd-vo Sankt-Peterburgskogo universiteta, 2001. 188 s.

[28] Hudjakov V.N. Formirovanie matematicheskoj kul'tury uchashhihsja nachal'nogo professional'nogo obrazovanija [Formation of mathematical culture of pupils of primary professional education]: diss. ... d-ra ped. nauk. Magnitogorsk, 2001. 349 p.

[29] Hutorskoj A.V. Sovremennaja didaktika [Modern didactics]: ucheb. posobie. M.: Vysshaja shkola, 2007. $639 \mathrm{p}$. 
[30] Jurko V.A. Vvedenie v teoriju obratnyh spektral'nyh zadach [Introduction to the theory of inverse spectral problems]: monografija. M.: Fizmatlit, 2007. 384 p.

\section{История статьи:}

Дата поступления в редакцию: 20 июня 2017

Дата принятия к печати: 25 июля 2017

\section{Для цитирования:}

Корнилов В.С. Развитие у студентов прикладного математического мышления при обучении обратным и некорректным задачам // Вестник Российского университета дружбы народов. Серия «Информатизация образования». 2017. Т. 14. № 4. С. 493-501. DOI 10.22363/23128631-2017-14-4-493-501

\section{Сведения об авторе:}

Корнилов Виктор Семенович, доктор педагогических наук, кандидат физико-математических наук, профессор, заместитель заведующего кафедрой информатизации образования Московского городского педагогического университета. Контактная информация: e-mail: vs_kornilov@mail.ru 